\title{
GREY ZONE IN THE REAL ESTATE MARKET
}

\author{
Ewa Kucharska-Stasiak, prof. \\ Faculty of Economics and Sociology \\ University of Lodz \\ e-mail:ewkuchar@uni.lodz.pl
}

\begin{abstract}
The grey area exists in all countries of the world. It is visible in various areas of activity, which means that it is widespread. It is a sign of the weak state institutional structures and overregulation of the economy. Traces of it are also visible on the real estate market. This paper argues that the size of the shadow economy in the real estate market is significantly undervalued. For this purpose, areas of its occurrence which had not been included in previous estimates were indicated, prepared by the Central Statistical Office and the Gdansk Institute for Market Economics. Two ways of tracking the grey zone were used: press reports and case studies.
\end{abstract}

Key words: grey economy, informal economy, real estate market.

JEL Classification: R30, L85.

Citation: Kucharska-Stasiak E., 2016, Grey Zone in the Real Estate Market, Real Estate Management and Valuation, vol. 24, no. 3, pp. 83-92.

DOI: $10.1515 /$ remav-2016-0023

\section{Introduction}

The grey area occurs in different areas of human activity, revealing itself with an uneven force. We argue that the real estate market is particularly predisposed to its development. The aim of this study is to present the available estimates of the size of the grey economy in the real estate market and indicate the causes of its relatively high proportions. We argue that the exposed size of the informal zone in the real estate market is undervalued.

\section{Conceptual scope of the grey area}

The common meaning of the term "grey zone" refers to activities which, for various reasons, elude official statistics. ${ }^{1}$ The PWN Dictionary of Economics defines the grey zone as illegal economic activity not reported within the country's tax and social security systems in force, and not subject to other requirements of public authorities (SŁOWNIK EKONOMII 2008, p. 469).

Both the definition of the grey area and its scope remain debatable. It is emphasized that there is no single definition, which depends on the purpose of the research and on the adopted methods of estimation. The problems with the definition are evidenced by the multitude of terms used to define this phenomenon, such as: informal economy, shadow economy, grey economy, parallel economy, unofficial economy, illegal, unrecorded economy, non-observed economy, second circuit economy, clandestine economy, underground economy, cash economy, or moonlighting (ŁAPIŃSKI et al. 2015). The term takes on a different look, different shades of grey as defined by B. Mika (MIKA 2010, p. 211).

The grey area has been included in national accounts. According to the convention adopted in the European system of national and regional accounts (MIKA 2010, p. 211) (the so-called ESA 2010 European System of Accounts) the informal economy, named the unobserved economy in this document (p. 11.26 of the Ordinance), includes three types of activities:

${ }^{1}$ For more on the grey zone: A. Grynia, E. Kucharska- Stasiak, A. Malarewicz- Jakubow,A. Miiller, J. Słoniec, Różne oblicza gospodarki nieformalnej [Different Faces of the Informal Economy], TEXTER, 2015 
1. Illegal activities (the smuggling of cigarettes, alcohol, drug dealing, prostitution, illegal medical practices or production of medicines). Illegal activities can be carried out by both, unregistered and registered economic entities.

2. Hidden activities, where the transactions themselves are not illegal, but are unreported in order to avoid official scrutiny. These activities are manifested by lowering turnover in order to avoid taxes, or failure to comply with the standards provided by law. Such activities are mostly carried out by small and medium-sized enterprises.

3. Activities referred to as informal, typically where no records are kept. They are conducted primarily by individuals in a casual, seasonal way. In general, they are characterized by a small scale. These activities are carried out often by the low-skilled unemployed, people employed in the formal economy, who take up work in the informal sector often using the employer's equipment and materials, or pensioners and students, as well as immigrants from the East, ready to take up work for low wages (ŁAPIŃSKI et al. 2015, p. 11).

The criterion for including economic activity in the informal sector is the creation of added value, obtained in voluntary market transactions which are not registered. "The effect of these transactions (...) is the production of goods and services, the use of this production in the form of consumption or accumulation and creation of incomes which find their way into economic circulation" (EAPIŃSKI et al. 2015, p. 8-9).

The grey zone - in accordance with the referenced EU regulations - does not include criminal activities, such as bribes, theft ${ }^{2}$ or money laundering. The production of households for personal use, although not subject to fiscal control, is not recognized as a grey zone either. ${ }^{3}$

The grey zone exists in every state, which means that all countries must have common reasons for its occurrence. However, the different scale of the occurrence of the informal economy suggests that, in addition to the differences in the intensity of the common reasons, there may occur reasons specific to a particular economy (e.g., a period of transformation) or particular culture (social acceptance of those operating in the grey area) (FEJGE 1989 pp. 295-360). Among the reasons determining the existence of the grey economy, are: market factors (high labor costs, poor access to information, insufficient income, lack of legal work, the fear of losing social benefits), institutional factors (high taxes, ease of obtaining social benefits, and psychological factors (tax morality, the impact on the environment) (PASTERNAK-MALICk 2013 pp. 43-44). The grey zone reacts strongly to negative shocks in the economy and less so to positive shocks (BAJADA 2003).

Research indicates that the shadow economy is sensitive to interference of the state in economic life and excessive fiscal policy (BEDNARSKI et al. 2008, p. 32). F. Schneider showed that the strongest correlation exists between the size of the grey market and the level of taxes and social insurance contribution - correlation coefficient of 0.56 (SCHNEIDER 2009 p. 4). The influence of this factor on the formation of the grey zone is estimated at the level of 35-38\%. In light of these studies, the impact of low tax morality determines the size of the grey economy at the level of 22-25\%. Other factors involved are the poor quality of public services and state institutions, including service provided by tax and treasury personnel. Overly restrictive labor market regulations are also important. Among the additional economic factors conducive to the formation of the grey economy, major causative factors include: changes in the structure of the economy, consisting of the growth of the service sector, which is relatively more prone to concealing turnover and unregistered employment, rising unemployment which triggers defensive reactions, changes in the ownership structure, changes in the number and size structure of enterprises: on the one hand, the emergence of a large number of small enterprises in which it is easier to conceal income and which are characterized by a weaker ethical attitude, on the other hand, the concentration of capital in large enterprises, which (using aggressive accounting) understate the basis for calculating taxes and fees. Also important are market pressure to reduce labor costs in order to increase competitive abilities, low wages which motivate workers to seek additional sources of income, demographic phenomena which, on one hand, are accompanied by the increase in young retirees and, on the other, large amounts of young people who do not have job opportunities in

\footnotetext{
2 The Regulation of the European Parliament and of the Council of the EU clarifies that illegal activities where one of the parties is not a willing partner (e.g., theft) is not an economic transaction and is not recognized within the limits of production (Section 11.26 of the Regulation). Only those illegal economic activities can be considered as economic transactions in which the parties engage by mutual agreement. Thus, purchases, sales or barters of illegal drugs or stolen property are transactions, while theft itself is not (Section 1.79 of the Regulation).

${ }^{3}$ In result, the economic income is different from the fiscal income.
} 
the official economy, and unstable tax legislation along with a complicated tax system (BEDNARSKI et al. 2008, pp. 35-36; GÓRKA 2011, pp. 55-56; WĄSOWSKI www.twoja-firma.pl/wiadomość/16807188). "The informal economy is a spontaneous and creative response of people to the state's inability to meet the basic needs of the impoverished masses" (DE SOTO 1991 p. 10). H. de Soto, creating a study of the Peruvian informal economy, stated that "... the limits of informality are determined not so much by the characteristics of economic activities, but their institutional framework" (DE SOTO 1991 p. 24).

To sum up, the grey economy is developing in the overregulated economy, in which laws are complicated and inconsistent, which contributes to high transaction costs and, additionally, there is social acceptance to evade the law and the lack of appropriate standards of ethical conduct. In countries where manifestation of disobedience is high and accompanied by social acceptance of tax evasion, and low tax morality is seen as a sign of resourcefulness, the grey area will be larger.

\section{The real estate market as a potential area for the occurrence of the grey zone}

We argue that the real estate market is very susceptible to the effects of the grey economy. Some authors consider this susceptibility to be a specific feature of this market (BRYX 2006, p. 49). The emergence of a grey area in the real estate market is fostered by:

- A great deal of public intervention. The government and local authorities affect the real estate market by imposing a legislative framework: actions through the spatial development policy, regulations on the flow of foreign capital, rent controls or property taxes, tax reliefs, subsidies for the acquisition of property, protection of agricultural land and forests, protection of monuments, or even by the number of the issued building permits. These regulations determine the availability of land for a particular function, rental rates, operating expenses, the size and cost of implemented repairs and modernization, as well as adaptation, affecting the demand and supply side (i.e., rent control in housing may increase the demand for dwellings, reducing the interest of private capital to build apartments for rental). The public sector (government and local authorities) indirectly affect the behavior of market participants through instruments such as taxation, regional policy, rent policy or the preservation of historic monuments.

- The ease with which real estate can be taxed, which is due to its permanent location, making it possible to identify the owner and easily enforce debts and obligations imposed on the property. This feature, combined with high capital intensity, means that the fiscal burden is substantial.

- High market imperfection also caused by its poor transparency, a relatively small number of transactions, and low liquidity of real estate. The share of private transactions in the real estate market is significant, and their course and prices are usually secret. The informal nature of the information and confidentiality of transactions, make gathering information about this market difficult and expensive.

- Strong informal limitations in the functioning of the real estate market. They reflect deeplyrooted social attitudes, e.g. respect for ownership and attachment to it, social behavior norms, and the rules of doing business, based on tradition and practice. These restrictions produce transaction costs which are only partially measurable, e.g., agency fees, state imposed fees, notary fees, and valuation costs. Most of these costs are difficult to measure, e.g. the cost of obtaining information on the real estate market, the delay in concluding notarial acts (resulting, e.g. from the right of first refusal or permission to purchase real estate by foreigners), the cost of local conflicts hindering the commencement of work or halting construction, costs resulting from the restrictions of excessive historic protection and the lobby of the Green Party [activities of environmental groups].

- The dominance of small entities. Among more than 218 thousand entities registered at the end of 2013 by the CSO in the "real estate services" as many as 214.5 thousand entities are classified in the category employing up to 9 people, only 73 employed 250 or more employees (KALKOWSKI 2015, p. 79). It is widely recognized that small businesses can hide income easier, and also take weaker ethical positions. M. Bednarski notes that, "small entrepreneurs can easily lose their business, and then it is difficult to rebuild it. The only hope may be to move into the grey zone, free of many burdens, which may allow the company to exist" (BEDNARSKI 2013, p. 48). Entering the underground economy, however, becomes a trap, because a company in the shadow economy has "... difficult access to capital, corporate networks (the products produced here are outside the records, 'laundering' them requires illegal activities), good staff, international exchange and support programmes 
for SMEs. Consequently, it is difficult to get back on the legitimate market (...). Thus, in this situation, operating in the grey area becomes a must" (BEDNARSKI 2013, p. 48).

To sum up, the strength of legal regulations in the real estate market, the highly developed fiscal function of real estate, the lack of market transparency, and the dominance of small businesses create good conditions for the formation and development of the shadow economy.

\section{Activities forming an area of the shadow economy in the real estate market}

The grey zone is identified with a world parallel to the official one, with space of a large volume and diversified composition (BEDNARSKI 2013, p. 53). According to the European system of national and regional accounts, it comprises two main types of behavior: voluntary market transactions, which are unreported ${ }^{4}$, as well as unreported employment.

The real estate market demonstrates activities belonging to each of the above-mentioned groups. Typical activities in the informal sector are:

- Understatement of the property's purchase price disclosed in the notary deed. The transaction is accompanied by an informal additional payment.

- Understatement of rental fees disclosed in the contract for the rental of commercial premises.

- Overstatement of rental charges in order to generate costs related to business activities conducted in the same premises, which in turn lowers the basis of taxable income.

- Rental of residential premises under a lending agreement, which means that the tenant officially pays only the cost of maintaining the property. The rent remains outside the reported income.

- Collecting rental fees for residential dwellings without lease agreements.

- Understatement of rental rates in the lease agreement.

- Understatement or overstatement of the disclosed value of the property.

- Collecting fees for the lease of land without concluding lease agreements.

There is also the phenomenon of unreported work in the real estate market, e.g. in the area of providing real estate agency services. Registered operators also employ workers through so-called "junk" service contracts and sign employment contracts indicating lower wages than actually received by the employee.

All these actions are aimed at one thing: avoiding taxes, which is typical for the grey zone. Lower purchase prices and rental rates, and unreported rental fees increase income. Striving to understate the value of real estate makes it possible to achieve certain benefits, e.g. when dividing the property, or overstating the value to obtain higher insurance compensation. Hiring workers under "junk" contracts as well as reporting lower wages can reduce the burden of payments to be made to the Social Insurance Institution.

But the assortment of "sins" committed in the real estate market is much more extensive, for example:

- Deliberate avoidance of the planning fee. The planning fee, in accordance with the Law on Spatial Planning and Development is payable, if a new local development plan is adopted or changed and the value of the property increases, with its owner selling it within five years after the plan has entered into force. To avoid the planning fee, the amount of which can reach up to $30 \%$ of the difference in value (before and after the change) specified by the real estate valuer, market participants prolong the transaction: they conclude a notary promissory future sales agreement, collect a significant part of the agreed price, and sign the actual contract of sale after the required statutory period.

- Unjustified financial benefits resulting from undue rights: There are tenants who live in communal flats (owned by the municipality, but also even in buildings owned by the Social Housing Association (TBS), who have the right to lease these premises. The lease right is not transferable. A tenant moves out of such a flat, but wants to make money on the lease right. The "old" tenant expects so-called "odstepne" from the "new" tenant. The "odstepne", is a "smartmoney" compensation for surrender of the lease right. This odstepne is higher in communal flats, because new tenants have the possibility to buy the dwelling with a discount, paying 10-15\% of its market value for a flat. It is also possible to buy a flat from the TBS. The phenomenon of

\footnotetext{
4 These transactions result in the production of goods and services, the use of this production in the form of consumption or the accumulation and creation of incomes which find their way into economic circulation.
} 
odstepne also appears in private tenement houses where, the owner additionally demands odstepne from the new tenant. Everywhere, odstepne is an expression of the large size of unmet housing needs and the lack of flats for rent.

- Unjustified coming into possession of a property after the death of a tenant of a communal flat and selling it. Studies for Poland show that for 1,000 deaths, municipalities recover only 12 apartments. ${ }^{5}$

\section{An attempt at a numerical approach to the grey zone}

\subsection{The real estate market in public statistics}

The real estate market is not separately distinguished in official statistics. The Polish Classification of Activities (PKD) distinguishes section L "Activities related to real estate services", which specifies:

- Buying and selling real estate on their own.

- Rental and management of their own or leased real estate.

- Activities related to commissioned real estate services (agency in real estate and management of real estate under contract) (ZAŁĄCZNIK Do ROZPORZĄDZENIA RADY MINISTRÓW ... 2007)

This classification does not represent all areas of the real estate market. L. Kałkowski points out that because of "... the lack of a source database from public statistics, most publications on the real estate market are of a fragmentary nature" (RYNEK NIERUCHOMOŚCI ... 2001, p. 55). It can be assumed that:

- Activities classified in the grey zone in the real estate market are hidden in the form of undisclosed turnover and unregistered employment in other sectors of the economy, e.g. warehousing and supporting activities for transportation, as well as activities related to accommodation and catering services. Both warehouses and hotels are properties, forming important real estate sub-markets: the market of warehouse property and the market of hotel spaces.

- The above activities, creating a grey area in the real estate market (Section 3), suggest that the majority of the informal economy remains outside public statistics.

\subsection{The real estate market as a segment of the informal economy in the light of research}

The grey zone is identified with a world parallel to the official one, with space of a large volume and diversified composition (BEDNARSKI 2013, p. 53). It is difficult to estimate its size (THOMAS 1999 pp. 381-389, TANZI 1999 pp. 338-347). To estimate the informal economy one cannot use the traditional methods based on "hard" information because the activities are hidden and thus avoid direct registration. An attempt to measure the grey zone is like tracking down footprints (EAPIŃSKI et al. 2015, p. 17).

Research on the informal economy sometimes reveals its structure showing the resultant added value as well as the estimate of employment in the individual sections. Disaggregation makes it possible to assess not only the place of the emergence and size of the grey economy but also its impact on economic recovery (ZARYCHTA 1993, p. 22).

The purpose of this inquiry is an attempt to capture the real estate market as an area of occurrence of the grey zone. It is worth noting that literature focuses primarily on the results of studies, without presenting in detail the research methods used in these studies.

According to research of F. Schneider, covering five countries (Spain, Italy, Germany, Turkey, and Poland), property rental and occupational activity in this market was estimated at $8 \%$ of the total estimated zone. Undeclared work prevailed, with the share of hidden turnover being smaller. Other sectors create a much larger volume of the shadow zone: construction, industry and trade and repairs, together, generate almost 37\% of the informal economy (SCHNEIDER 2009). In construction and industry, the grey zone consists mainly of unregistered workers. In the construction industry, it has taken on the form of a habit, especially when hiring subcontractors (SCHNEIDER 2009, p. 9). An important reason for the dominance of these sectors is also the large proportion of small transactions, paid cash-in-hand. On the other hand, the sectors: trade and repairs, hotels and restaurants, and transport and communication, which account for $20-25 \%$ of the grey zone, are dominated by hidden

\footnotetext{
5 Cf. J. Korniłowicz, Aspekty społeczne, ekonomiczne i techniczne komunalnych zasobów mieszkaniowych [Social, Economic, and Technical Aspects of Municipal Housing], Instytut Rozwoju Miast (Institute of Urban Development), typescript
} 
turnover (SCHNEIDER 2009, p. 9). The share of the real estate market in the five countries surveyed has been presented in Table 1.

Table 1

The grey zone in real estate services in the countries surveyed

\begin{tabular}{lccccc}
\hline \multicolumn{1}{c}{ Specification } & Germany & Spain & Italy & Poland & Turkey \\
\hline $\begin{array}{l}\text { The share of the grey zone in real } \\
\text { estate services (Section } \mathrm{K}^{6} \text { ) }\end{array}$ & 5 & 10 & 10 & $\mathbf{0}^{7}$ & 20 \\
\hline The overall share of the grey zone & 15.4 & 21.3 & 21.4 & 28.7 & 32.5 \\
\hline
\end{tabular}

Source: Schneider (2009, pp.14-16).

The research cited by Górka revealed that value added in the informal economy is obtained primarily in trade and repairs (40-50\%), industry (15-25\%) and construction (7-10\%). To a lesser extent, it is created by transport (4-5\%), real estate services and business services, and other sections of economic activity. Similarly to F. Schneider's research, the above data suggest that the informal economy in the real estate market is relatively small; also, the structure of employment in the informal economy, demonstrated by the author, does not expose the real estate market. The dominant services include: construction and renovation, and construction and installation repairs (26-27\%), garden and agriculture work (24-25\%), renovation services (12-13\%), trade (without repairs) 8-9\%, overhaul and repairs of cars $(6-7 \%)$, tailoring services $(6-7 \%)$, transport services $(5-6 \%)$, care of children and the elderly (4-5\%) and private lessons (4\%) (GóRKA 2011 p. 63).

Different conclusions can be drawn from the analysis of the structure of the grey zone presented by K. Szawałek who analyzed the structure of the grey zone and estimated its share in the real estate market in 2002 at around 16\% in turnover and slightly less than $16 \%$ in employment - Table 2 . In terms of turnover, a higher share was demonstrated in construction, trade, telecommunications, transport and industry. A higher share of undeclared employment took place in the construction, telecommunications, transport and trade sectors of the economy.

Table 2

Share of the grey zone in the annual turnover of the Polish economy in 2002, in \%

\begin{tabular}{lcc}
\hline \multicolumn{1}{c}{ Section } & Share in turnover & Share in employment \\
\hline Processing industry & 17.1 & 14.0 \\
\hline Construction & 26.0 & 27.3 \\
\hline Trade & 21.3 & 18.7 \\
\hline Hotels and restaurants & 13.8 & 15.8 \\
\hline Telecommunications and transport & 20.9 & 22.2 \\
\hline Real estate & $\mathbf{1 6 . 0}$ & $\mathbf{1 5 . 8}$ \\
\hline Education & 12.1 & 12.5 \\
\hline Health Services & 12.7 & 5.5 \\
\hline Total & 20.2 & 18.6 \\
\hline
\end{tabular}

Source: Szawałek (2003, p. 13).

The Central Statistical Office (Gtówny Urząd Statystyczny - GUS) also conducted research on the estimates of the share of the grey economy in GDP by sections - see Table 3. In 2010, the share of the shadow economy in GDP in the section "Real estate services" was estimated at 1.0\%. A higher share was recorded only in the following sections: trade and repair of motor vehicles, accommodation and catering (5.8\%) and construction (2.4\%). Between 2010 and 2013, the share of the shadow economy in the real estate market showed an increase from $1.0 \%$ to $1.4 \%$.

The estimates of the shadow economy in light of various studies show similarities, but also differences. In all studies, the sector "Real estate services", identified with the real estate market, is an area characterized by the formation of the grey zone. It does not, however, assume a leading role in

\footnotetext{
6 This classification is consistent with the European Classification of Activities, which was in force in Poland until 1999.

7 The result of the estimate is not clear, it is not correct.
} 
the shadow economy. Instead, the differences in the results concern its structure: F. Schneider's studies show that the sector is dominated by undeclared work, which significantly exceeds the concealed turnover, while Szawałek's research shows that the level of the shadow economy in both areas is comparable.

Table 3

Estimates of the size of the "grey economy" in GDP in 2009-2013 in current prices

\begin{tabular}{lcccc}
\hline Specification & $\mathbf{2 0 1 0}$ & $\mathbf{2 0 1 1}$ & $\mathbf{2 0 1 2}$ & $\mathbf{2 0 1 3}$ \\
\hline Industry & 1.3 & 1.1 & 1.4 & 1.5 \\
\hline Construction & 2.4 & 2.4 & 2.5 & 2.6 \\
\hline $\begin{array}{l}\text { Trade and repair of motor vehicles, } \\
\text { accommodation and catering }\end{array}$ & 5.8 & 5.6 & 6.1 & 6.1 \\
\hline Transportation and storage & 0.6 & 0.4 & 0.6 & 1.0 \\
\hline Real estate services & $\mathbf{1 . 0}$ & $\mathbf{1 . 1}$ & $\mathbf{1 . 6}$ & $\mathbf{1 . 4}$ \\
\hline Other sections & 1.5 & 1.5 & 1.8 & 1.9 \\
\hline
\end{tabular}

Source: National accounts by institutional sectors and sub-sectors in 2010-2013, Annex 3, GUS, Warsaw, August 2015.

We have argued that the grey area in the real estate market is undervalued. This was pointed by the Gdansk Institute for Market Economics for the first time, which corrected the GUS estimates for the whole economy, with activities which, according to the Institute, had not been taken into consideration by the GUS. In the real estate market, re-estimates covered property rental and the lease of land. Unfortunately, the Gdansk Institute for Market Economics, which rightly took into account property rental and the lease of land as an area of the creation of added value in the grey zone, did not provide the estimate results by sectors.

However, the enumeration of activities which create the shadow economy (see Section 3) still suggests that a significant part of the activities of informal economy have not been taken into account in the estimates of the Institute either.

\subsection{Tracking down footprints...}

Research of the grey area is certainly very difficult. The most commonly used classification of methods of measurement can be divided into two categories of estimates: direct and indirect methods (Metodologia Badań SZARej ... 2005 pp. 18-34; Mika 2010, pp. 220-221). The first category of methods makes it possible to enter the sectoral and product structure of the grey zone, the second is carried out at the level of national statistics in order to determine by how much higher GDP would be if the incomes were disclosed. The direct methods also employ surveys and fiscal control.

Studies on the grey zone emphasize that "One should not underestimate such possible observations of the grey zone as provided by literature, film, media and personal relationships (e.g., diaries). Therefore the substudies use the method of field research and case study" (METODOLOGIA BADAŃ SZAREJ ... 2005 p. 22).

In these considerations, we will use two ways of tracking the grey zone: press reports and case studies. They are not intended to estimate the size of the grey economy, their goal is to justify the accuracy of the thesis that the grey zone in the real estate market has been underestimated in statistics, by identifying the areas in which the zone occurs.

\subsubsection{Tracking down footprints: Grey area in the real estate market in the light of press reports}

Numerous traces of the grey zone can be found on the rental market. Most of them are on the housing market. This area of the grey economy is revealed in many countries throughout the world, it can be assumed that it is universal. The importance of rental income and property rights as an area of evading tax law in the United States has been indicated by J. Stiglitz, who claims that about $60 \%$ of this revenue is not reported. In 1992, the undisclosed income was estimated at about $\$ 22.2$ billion, and losses due to unpaid taxes reached $\$ 4.2$ billion (STIGLITZ 2004, pp. 854-855). It is estimated that, in Spain, more than half of the property owners do not pay taxes on lease. The Spanish union of tax inspectors, "... estimates that e owners earn about 2.5 billion euros annually by not paying taxes" (RYNEK NAJMU MIESZKAŃ ... 2010). Certainly, the scale of the problem is evidenced by comparing the number 
of apartments for rent (in 2008, an increase of 18\%), with the declared income of the owners (which increased only by 0.1 percent) (RYNEK NAJMU MIESZKAŃ ... 2010).

The housing rental market reveals that a way to reduce the informal economy is to reform the tax system: in 2010, the introduction of a single flat-rate tax of $8.5 \%$ on revenue, increased the number of taxpayers; in 2007, almost 134 thousand taxpayers took advantage of a flat-rate tax ${ }^{8}$, and after the reform of 2013, about 385 thousand people (www.ekonomia.rp.pl/artykul/1111711.html, 22 May 2014).

Press reports also draw attention to the existence of the grey economy in tourism (GRUSZYŃSKA 2014). "Although the number of foreign visitors to our country increases from year to year, apparently more and more of them are sleeping under bridges or on park benches. According to official statistics, last year alone the number of registered beds declined from 610 to 606 thousand. Just take a ride on the Baltic coast and you'll see that these statistics are nonsense, and the number of guest houses is increasing. However, the season on the Baltic Sea lasts only 50 days, and you have to pay fees and taxes throughout the year. That's why most of us have a choice: either to close down or run it at least partly secretly - says (...) the owner of one of the guest houses in Krynica Morska, who for obvious reasons asked to remain anonymous" (BIELECKI 2012).

"It is estimated that in Zakopane, some 30 to $50 \%$ of the beds do not officially exist. This is the conclusion reached from the difference between the number of tourists coming here and registered beds" (BIELECKI 2012).

The real estate market also turned out to be a grateful place for the unregistered work performed by people who have set up, for example "Property Management" or "Property Valuation" registered businesses, but in fact undertake activities in the area of a real estate agency, without paying taxes on the resulting commission. There are also "freelancers" on this market, who do business without any registration, hiding the entire income. These activities are certainly fostered by the deregulation of two professions in the real estate market: real estate agents and real estate managers. Today, you do not need to have any preparation, any confirmation of having the necessary knowledge, or any commitment to comply with the code of professional ethics, to enter the market for "a couple of shots."

There are also more sophisticated sources of achieving illegal, untaxed income in this market. One of them is collecting the so-called odstęne "smart-money", compensation for surrender of lease. How widespread this phenomenon is, is evidenced by the number of press announcements. On two websites alone (mieszkanie.mitula.com.pl; olx.pl/oferta), on 28 December 2015, there were 56 ads. They concerned not only apartments but also commercial premises, for a pastry shop, a restaurant or office function. These were mainly premises in private buildings, but the ads involved also communal (municipality) apartments, and those owned by the Social Housing Association (TBS). ${ }^{9}$

The ads were submitted directly by the owners, current tenants but also by real estate agents. Many of these announcements concerned unfurnished premises, intended for repair. In addition to ads such as "I want to give away a flat for the odstepne", they frequently used the phrase "I want to sell a flat for odstęne", which can be misleading to potential buyers. ${ }^{10}$ The expected amount of the odstepne varied widely, ranging from 16.5 thousand to 100 thousand zlotys. In practice, the amount depends on the standard of the premises and the amount of rent you pay (the lower the rent, the higher the amount of the odstęne), but also on the form of possession. It was higher for communal flats which could be bought with high discounts. Bogus residence registrations, the fictitious exchange of flats and money by the tens of thousands transferred without any invoices - for many market participants, this is the way of obtaining an apartment for half its value.

\subsubsection{Case studies}

The prevalence of the odstępne phenomenon on the real estate market encouraged us to examine several cases.

\footnotetext{
8 Until 2010, there were two tax rates: $8.5 \%$ for revenues up to 4 thousand euro and $20 \%$ above this amount. See: http:/ / porady.domiporta.pl/poradnik/1,127301,6367738 of 11 March 2009.

9 The reason for trading of premises in the TBSs are loopholes in the Act on certain forms of support for housing construction. It lacks provisions prohibiting transfer of rights

and obligations under the participatory agreement in the TBS. Since 2004, the TBSs are already posting such a clause.

10 An example is described in the Dziennik Łódzki, the transaction was carried out through a real estate agency http://www.dzienniklodzki.pl/artykul/350804,lodz-zadziwiajaca-historia-mieszkania-w-kamienicy-przywolczanskiej,id,t.html
} 
Case No. 1 - Acquisition of lease rights with so-called residence registration for an indefinite period in private multi-apartment property

Mr. X, in order to acquire the lease right to a tenement house, not only had to pay the owner a onetime deposit of a 6-month's rent, but also a one-time payment in the form of odstepne. In the present case, for the 26 square meter dwelling in the centre of a big city, the amount was 20 thousand zlotys. This amount was not reported. The official reason for its collection is the return of expenditures incurred by the owner for repairs. This justification is not appropriate, since it was not the ownership right which was traded here, but the lease right. The tenant should not be charged for the repair, since a higher technical and utility standard is reflected by a higher rent.

Case No. 2 - Acquisition of lease rights with so-called residence registration for an indefinite period in communal (municipality) multi-apartment property

Ms. $Y$, in order to acquire the right to lease property belonging to the municipality, had to pay, in addition to the deposit, odstepne to the tenant who was leaving the apartment. In the case of municipal property, the odstepne was 50\% higher than in a private house; it was, in fact, approximately 30 thousand zlotys. She agreed, because the right to lease enables her to buy the premises from the municipality with a very large discount of up to $80-90 \%$ of the value of the property. This means that the tenant may become the owner of the property, paying $10-20 \%$ of its value.

Case No. 3 - Acquisition of lease rights to a 50 sq. $\mathrm{m}$ dwelling in a new building owned by the TBS. A person who has entered into an agreement with the association regarding participation in the costs of the construction of the apartment gives up waiting for the conclusion of the lease agreement and waives his/her place to Ms. Z. The location in the greenbelt, the technical condition and the standard of use of the building and dwelling convinced Mrs. Z to pay as much as 100 thousand for the odstepne.

\section{Summary}

Grey economy is widespread, which means that it occurs in all areas of human activity. The characteristics of property and the real estate market mean that the market turns out to be very susceptible to the formation of the shadow economy. Susceptibility to activities in the area of the informal economy is even considered to be a feature of this market. In the light of press reports and a "sneak peek" at the behaviors of market participants, it seems that the thesis put forward in this study, i.e. that the size of the grey economy in the real estate market in Poland is not properly estimated, is right. The Gdansk Institute for Market Economics has noticed that, in its estimates, the Central Statistical Office had not taken into account the untaxed income resulting from the rental of apartments and land lease. Hence, it would appear that the Institute's estimates also do not reflect all of the often occurring processes in the area of the grey zone (Section 4.1 to 4.2). In addition to commonly occurring sources making up the grey zone, the present research has made an attempt to trace the phenomenon of the odstepne.

\section{References}

BAJADA CH., 2003, Business Cycle Properties of the Legitimate and Underground Economy In Australia, The Economic Record, Volume 79, No. 247.

BedNARSKI M., KRYŃSKA E., PATER K., WALEWSKI M. (eds.), 2008, Szara strefa- rynek pracy- integracja społeczna [Grey Zone - Labour Market - Social Integration], Optimum. Studia Ekonomiczne, 2013 , No. 6(66), Przyczyny pracy nierejestrowanej w Polsce [The reasons for undeclared work in Poland], Ministry of Labour and Social Policy, Labour Market Department, Warsaw.

BIELECKI J., 2012, Szara strefa, błogosławieństwo kapitalizmu (The Grey Zone, a Blessing of Capitalism), Gazeta Prawna.Pl, 13 January 2012.

BRYX M., 2006, Rynek nieruchomości. System i funkcjonowanie (Real Estate Market. System and Functioning), Poltext, Warsaw.

FEIGE E.L., 1989, The Underground Economies Tax Evasion and Information Distortion, Cambridge University Press.

GóRKA K., 2011, Kierunki zmian gospodarki nieformalnej w Polsce (Trends in the Informal Economy in Poland), Zeszyty Naukowe Uniwersytetu Ekonomicznego w Krakowie, Issue No. 860.

GRUSZYŃSKA A., 2014, Wakacyjne kontrole fiskusa. Przeciwko szarej strefie w miejscowościach turystycznych [Tax Authorities' Inspections During Vacation: Against the Grey Zone in Tourist Destinations], Wyborcza. biz/WIADOMOSCI, 11 August 2014. 
Grynia A., Kucharska- Stasiak E., Malarewicz- Jakubow A., Milller A., SŁoniec J., 2015, Różne oblicza gospodarki nieformalnej (Different Faces of the Informal Economy), TEXTER.

KAŁKOWSKI L., 2015, 25 lat polskiego rynku nieruchomości. Monitoring za lata 1990-2014 (25 Years of Polish Real Estate Market: Monitoring for the Years 1990-2014), Instytut Rozwoju Miast, Cracow.

KORNIŁOWICZ J., Aspekty społeczne, ekonomiczne i techniczne komunalnych zasobów mieszkaniowych (Social, Economic, and Technical Aspects of Municipal Housing), Instytut Rozwoju Miast, typescript.

ŁAPIŃSKI K., PETERLIK M., WYŹNIKIEWICZ B., 2015, Szara strefa w polskiej gospodarce w 2015 roku (The Grey Zone in the Polish Economy in the Year 2015), Instytut Badan nad Gospodarką Rynkową, Warsaw, March 2015.

Metodologia badań szarej strefy na rynku ustug turystycznych [Methodology of Research on the Grey Economy on the Tourism Service Market], 2005, collective work, Instytut Koniunktur i Cen Handlu Zagranicznego, Warsaw.

MIKA B., 2010, Wszystkie odcienie szarości- kilka uwag o gospodarce ukrytej [All Shades of Grey: A Few Remarks About the Hidden Economy], [in:] Struktura klasowo-stanowa społeczności Poznania [The Class-State Structure of the Community of Poznan], ed. J. Tittenbrun, Poznan: Nakom.

PASTERNAK-MALICKA M., 2013, Zatrudnienie nierejestrowane w kontekście polityki bezrobocia w Polsce (Unregistered Employment in the Context of Unemployment Policy in Poland), Studia BAS, No. 4(36).

Rachunki narodowe wedtug sektorów i podsektorów instytucjonalnych w latach 2010-2013 (National Accounts by Institutional Sectors and Sub-sectors in the Years 2010-2013), 2015, GUS, Warsaw August 2015.

Rozporzadzenie Parlamentu Europejskiego i Rady (UE) nr 549/2013 z dnia 21 maja 2013 roku w sprawie europejskiego systemu rachunków narodowych $i$ regionalnych $w$ Unii Europejskiej (Regulation of the European Parliament and of the Council (EU) No 549/2013 of 21 May 2013 on the European system of national and regional accounts in the European Union), 2013, Official Journal of the European Union L174, Polish edition, Legislacja, Volume 56, June 26, 2013.

Rynek najmu mieszkań w Hiszpanii uciekt do szarej strefy (Housing Rental Market in Spain has Fled to the Informal Econom), 2010, Dziennik Gazeta Prawna of 3 February 2010.

Rynek nieruchomości w Polsce (The Real Estate Market in Poland), 2001, collective work edited by L. KAŁKOWSKI, Twigger, Warsaw.

SCHNEIDER F., 2009, The Shadow Economy in Europe, A.T. KEARNEY, Johannes Kepler Universiteat Linz.

De Soto H., 1991, Inny szlak (The Other Path. Invisible Revolution in the Third World), Polskie Towarzystwo Współpracy z Klubem Rzymski, Warsaw, introduction by Mario Vargas Llosa.

SŁOWNIK EKONOMII [Dictionary of Economics], 2008, Wydawnictwo Naukowe PWN, Warsaw.

STIGLITZ J. E., 2004, Ekonomia sektora publicznego (Economics of the Public Sector), Wydawnictwo Naukowe PWN, Warsaw.

SZAWAŁEK K., 2003, Ostrożnie z wybielaniem. Raport specjalny: szara strefa (Careful with the Laundering. Special Report: Grey Area), Business Week- Polish Edition, No. 8.

TANZI V., 1999, Uses and Abuses of Estimates of the Underground Economy, The Economic Journal, Volume 109.

THOMAS J., 1999, Quantifying the Black Economy: "Measurement without theory" yet again?, The Economic Journal, Volume 109.

WĄSOWSKI W., Wtadztwo korporacyjne w gospodarce cienia (Corporate Governance in the Shadow Economy), www.twoja-firma.pl/wiadomość/16807188.

ZARYCHTA H., 1993, Szara strefa rynku pracy w Polsce (The Grey Area of the Labor Market in Poland) (I), Praca I Zabezpieczenie Społeczne, No. 12.

Załącznik do Rozporządzenia Rady Ministrów z dnia 24 grudnia 2007 roku w sprawie Polskiej Klasyfikacji Dziatalności (Annex to the Regulation of the Council of Ministers of 24 December 2007 on the Polish Classification of Activities), Journal of Laws RP 2007, No. 251, item. 1885.

porady.domiporta.pl/poradnik/1,127301,6367738 11 March 2009.

www.ekonomia.rp.pl/artykul/1111711.html 22 May 2014.

mieszkanie.mitula.com.pl.

olx.pl/oferta.

www.dzienniklodzki.pl/artykul/350804,lodz-zadziwiajaca-historia-mieszkania-w-kamienicy-przywolczanskiej,id,t.html. 